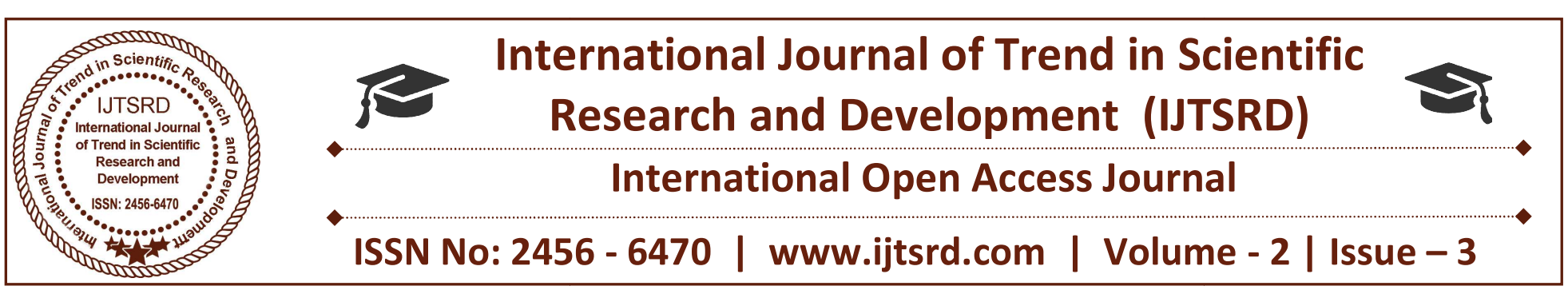

\title{
Soil Liquefaction Potential Maps for Earthquake Events in Yangon, Myanmar
}

\author{
Zar Lee Tint, Nyan Myint Kyaw, Kyaw Kyaw
}

Department of Civil Engineering, Yangon Technological University, Yangon and 11181, Myanmar

\begin{abstract}
The soil liquefaction is one of the main topics of geotechnical engineering associated with the strong earthquakes. The study area has been selected in Yangon City because it is most populated density area and located near the active faults and the rivers. The main objective of study is the development of liquefaction potential maps as a prominent feature for site planners and decision makers to reduce loss of lives. The borehole data including ground water table, Standard Penetration Test (SPT), blow counts, wet density and fine content etc. have been collected from the 530 representative sites in Yangon City. The safety factor of soil liquefaction is evaluated by using National Center of Earthquake Engineering Research (NCEER) Method (1997). The Liquefaction Potential Index (LPI) is proposed by Luna and Frost Method (1998) to predict the potential of liquefaction at sites. The proposed liquefaction potential map is analyzed by using Geographic Information Software. The development of liquefaction potential maps is associated with $1 \%, 2 \%, 5 \%, 10 \%$ and $20 \%$ of probabilities of exceedance in 50 years.
\end{abstract}

Keywords: Liquefaction potential index, Geographic information system (GIS), Yangon City, Liquefaction potential map, Earthquake, Borehole data

\section{INTRODUCTION}

Liquefaction occurred in loose saturated cohesionless soil during the earthquakes is responsibility to structural failure and damage to roads, pipelines and infrastructures. It is one of the most geotechnical problems. The soil liquefaction depends on the different types of situations which are magnitude of earthquake, the distance from the source of the

earthquake, site-specific conditions, ground acceleration, type of soil and thickness of soil deposit, relative density, grain size distribution, fine content, plasticity of fines, fluctuation of groundwater table and reduction of effective stress [1].

The evaluation of the SPT-based liquefaction triggering database relative to the liquefaction triggering is correlated by Idriss and Boulanger (2004, 2008). The distributions of the data are examined with respect to various parameters (e.g., fines content, overburden stress, earthquake magnitude) and data sources (e.g., data from the U.S., Japan, pre- and post1985 studies, and sites with strong ground motion recordings) [2, 12]. Nowadays, there is no liquefaction potential map for Yangon and the data sources from Yangon are not considered the evaluation of liquefaction analysis in Myanmar.

Yangon City is located near the Sagaing Fault. The Bago (Pegu) earthquake (7.3 RS) of 5 May 1930 along the Sagaing Fault killed approximately 500 people in Bago and 50 in Yangon. In recent year, a lot of earthquakes have been occurred in Yangon Region area. In addition to, most of the area in the city composed of medium to fine sand and silty sand and sand containing low plasticity.

The simplified producer proposed by Seed et al (1971) was widely used for evaluation of safety factor of soil liquefaction. Most of the researchers had been modified and developed the methods of liquefaction analysis. The NCEER (1996) method proposed by many researcher was derived from SPT acquired at sites experiencing liquefaction in past earthquakes [2]. 
In this research, the safety factor of soil against liquefaction is evaluated by NCEER method with each depth along the soil profile during different earthquakes. The safety factor does not demonstrate the degree of liquefaction severity at different site locations [18]. So, the liquefaction potential index from the factor of safety proposed by using Luna and Frost method (1998) and then liquefaction potential maps have been developed by using LPI values at different parts of the city. The liquefaction map is prepared for earthquakes with $1 \%, 2 \%, 5 \%, 10 \%$ and $20 \%$ probabilities of exceedance in 50 years. In this research, the main objective is the proposed soil distribution maps and liquefaction potential maps for Yangon City area.

\section{GEOLOGY AND TECTONIC SETTINGS}

Yangon City, Myanmar, is situated between Latitude $16.8661^{\circ} \mathrm{N}$ and Longitude $96.1951^{\circ} \mathrm{E}$, on the southeastern corner of the Ayeyarwady Delta basin, at the mouth of three rivers: Yangon, Ngamoyeik and Bago rivers and $34 \mathrm{~km}$ from the sea in the coastal area. The Yangon area is mostly covered by alluvial deposits which are comprised of gravel, clay, silts, sands and laterite which lie upon the eroded surface of the Irrawaddy formation at $3-4.6 \mathrm{~m}$ above mean sea level (MSL) (Myo Thant, 2012) [9]. The soft rocks in Yangon comprise of sandstone, shale, limestone and conglomerate. Yangon City is the most populated area about six million people and financial city. A lot of tall buildings have been built in Yangon area. Many buildings in ancient parts of the City are nonstructural engineering designs. The geological map of the Yangon city is shown in Fig 1.

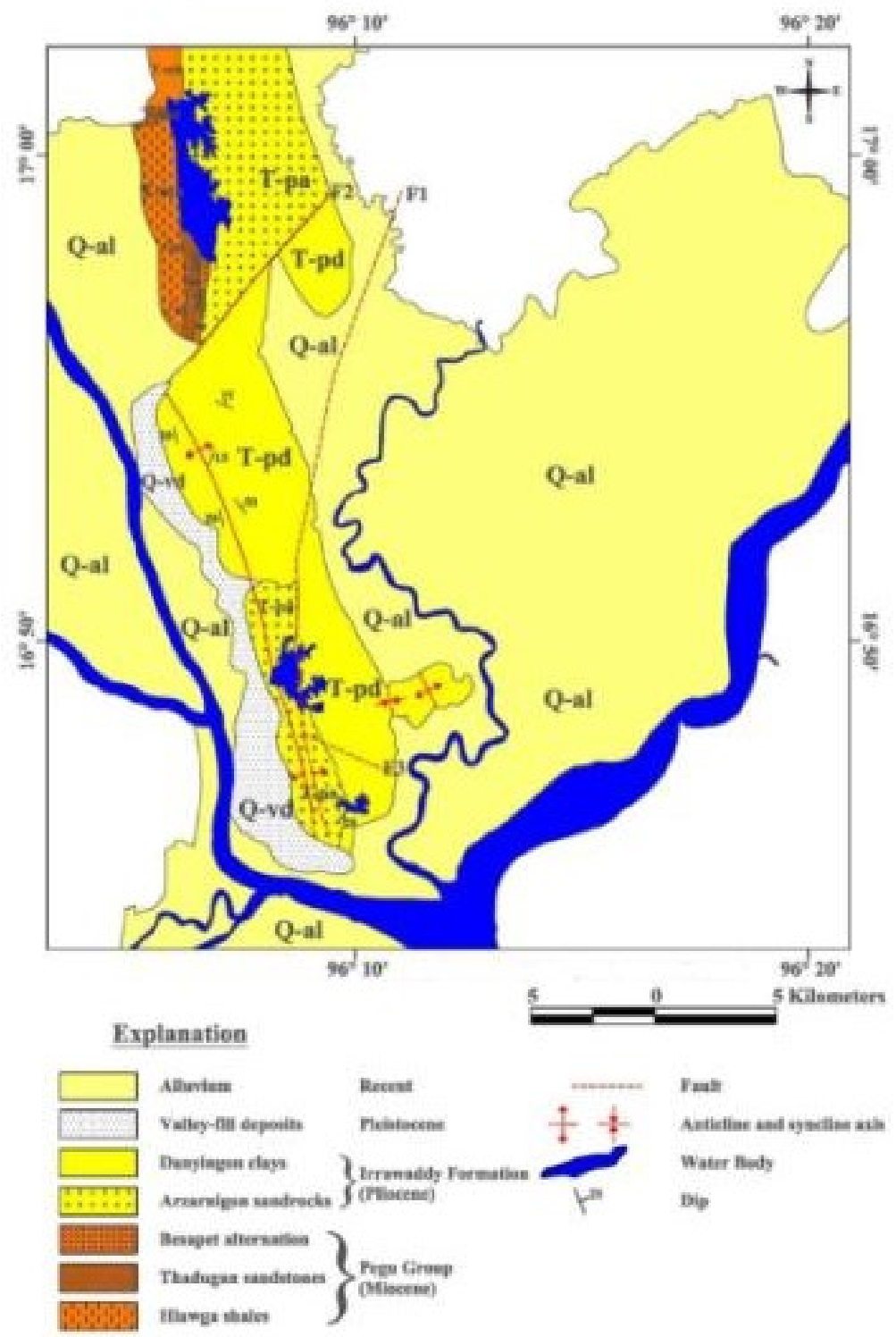

Figure 1. Geological Map of the Greater Yangon (Win Naing, 1972) 
The major tectonics of Myanmar consists of the subduction zone of Indian Plate beneath Burma Plate in the west and the collision zone of Indian Plate with Eurasia Plate in the north. The major active faults in Myanmar are Sagaing fault, Kyaukkyan fault, Gwegyo thrust, and West Bago Yoma fault. Most of the earthquakes, which occurred in the central region of Myanmar, are concerned with Sagaing fault, and in the eastern part, the focal depth is not greater than 40 $\mathrm{km}$ while the earthquakes in the western portion include from shallow, through intermediate to deep focus earthquakes [9]. The shallow focus earthquakes along the western margin belong to the subduction zone earthquakes and the focal depth of the earthquakes, which are generated from the subduction zone gradually increase to the eastward. In the eastern margin of the Western Ranges or Indoburma Ranges, the shallow focus events are corresponded with the crustal faults [9].

Yangon Region has been tectonically adjacent to the indian plates subduction in the west, Sagaing fault in the east, West Bago Yoma fault in the north, Kyaykkyan fault in the north-east, and the Andaman rift zone in the south. (Myo Thant, 2012) [9]. Yangon City has been chosen as the study area because most of the earthquakes in and around Yangon Region are shallow focus earthquakes related with Sagaing fault.

\section{EVALUATION OF LIQUEFACTION POTENTIAL INDEX DUE TO EARTHQUAKE}

The factor of safety against soil liquefaction is computed by using SPT based liquefaction producer that is recommended by NCEER method. The evaluation of Liquefaction potential index (LPI) proposed by Luna and Frost Method (1998) is taken the integration of one minus the liquefaction factors of safety along the entire depth of soil profiles limited to the depths ranging from 0 to $20 \mathrm{~m}$ below the ground surface at a specific location [3-8]. The categories of liquefaction severity with regard to LPI as per Iwasaki et al. (1982) and Luna and Frost (1998) are shown in Table 1 . The safety factor of liquefaction (FS) and the liquefaction potential index (LPI) are calculated based on the seismic demand expressed in terms of cyclic stress ratio (CSR) to the capacity of liquefaction resistance of the soil expressed in terms of cyclic resistance ratio (CRR).

\section{A. Determination of Liquefaction Potential of Soil}

Soil liquefaction is a phenomenon that has been occurred in a saturated or partially saturated soil substantially loses strength and stiffness in response to an applied stress during earthquake shaking or other sudden changes in stress condition, causing it to behave like a liquid.

Clayey soils with significant plastic fine should be calculated liquefaction possible recommended by Seed and Idriss (1983). It must meet all the following criteria:

Fraction finer than $0.005 \mathrm{~mm} \leq 15 \%$

Liquid Limit (LL) $\leq 35 \%$

Natural water content $\geq 0.9 \mathrm{LL}$

Liquid Index $\leq 0.75$

If the cohesive soil does not meet all criteria, then it is generally considered to be not susceptible to liquefaction. Although the cohesive soil may not liquefy, there could still be a significant undrained shear strength loss due to the seismic shaking (Robert W. Day, 2002) [5].

The soil with liquefaction susceptibility must be below the groundwater table. Liquefaction susceptibility decreases strongly with increasing depth to the water table (Robert W. Day, 2002) [5].

The cyclic resistance ratio $\left(\mathrm{CRR}_{\mathrm{M}=7.5)}\right)$ with earthquake magnitude $\left(\mathrm{M}_{\mathrm{w}}=7.5\right)$ developed by NCEER Method using corrected standard penetration test data is computed as [3-8]

$$
100 * \mathrm{CRR}_{\mathrm{M}=7.5}=\frac{95}{34-\left(\mathrm{N}_{1}\right)_{60}}+\frac{\left(\mathrm{N}_{1}\right)_{60}}{1.3}-\frac{1}{2}
$$

Where $\left(\mathrm{N}_{1}\right)_{60}$ is the corrected, clean-sand equivalent SPT value. It is provided a value of $\left(\mathrm{N}_{1}\right)_{60} \leq 30$ in this equation 1.

The corrected SPT blowcount proposed by Robertson and Fear (1996) is calculated with:

$$
\left(\mathrm{N}_{1}\right)_{60}=\mathrm{N}_{\mathrm{SPT}} \mathrm{C}_{\mathrm{N}} \mathrm{C}_{\mathrm{E}} \mathrm{C}_{\mathrm{B}} \mathrm{C}_{\mathrm{R}} \mathrm{C}_{\mathrm{S}}
$$

The correction factor $\left(\mathrm{C}_{\mathrm{N}}\right)$ normalizes the measured blowcount to an equivalent value under one atmosphere of effective overburden stress:

$$
\mathrm{C}_{\mathrm{N}}=\sqrt{\frac{\mathrm{p}_{\mathrm{a}}}{\sigma_{\mathrm{vo}}^{\prime}}} \leq 2.0
$$

Where $\sigma^{\prime}{ }_{\mathrm{v} 0}$ is the vertical effective stress at the depth of $\mathrm{N}_{\mathrm{SPT}}$ and $\mathrm{P}_{\mathrm{a}}$ is one atmosphere of pressure in the 
same units as $\sigma^{\prime}{ }_{\mathrm{v} 0}, \mathrm{C}_{\mathrm{E}}$ is corrected energy ratio, $\mathrm{C}_{\mathrm{B}}$ is the correction factor of borehole diameter, $\mathrm{C}_{\mathrm{R}}$ is correction factor for rod length and $\mathrm{C}_{\mathrm{S}}$ is the correction for sampler with or without liner.

The clean-sand equivalent is made based on the fines content of the soil sample:

clean - sand equivalent $\left(\mathrm{N}_{1}\right)_{60}=\left(\mathrm{N}_{1}\right)_{60}+\Delta\left(\mathrm{N}_{1}\right)_{60}$

The correction factor $\Delta\left(\mathrm{N}_{1}\right)_{60}$ is computed with the linear function:

- For $\mathrm{FC} \leq 5 \%$

$$
\Delta\left(\mathrm{N}_{1}\right)_{60}=0.0
$$

- For $5 \%<\mathrm{FC}<35 \%$

$$
\Delta\left(\mathrm{N}_{1}\right)_{60}=7 *(\mathrm{FC}-5) / 30
$$

- For $\mathrm{FC} \geq 35 \%$

$$
\Delta\left(\mathrm{N}_{1}\right)_{60}=7.0
$$

Where $\mathrm{FC}$ is the fines content (percent finer than $0.075 \mathrm{~mm})$

The cyclic stress ratio (CSR) proposed by Seed et al. (1985) is calculated as [10-17]

$$
\mathrm{CSR}=0.65 \frac{\mathrm{a}_{\max }}{\mathrm{g}} \frac{\sigma_{\mathrm{v} 0}}{\sigma_{\mathrm{v} 0}^{\prime}} \gamma_{\mathrm{d}}
$$

Where $g$ is the acceleration due to gravity $\left(9.81 \mathrm{~m} / \mathrm{s}^{2}\right)$, $\sigma_{\mathrm{v} 0}$ is the total vertical overburden stress, and $\sigma_{\mathrm{v} 0}^{\prime}$ is the effective vertical overburden stress at the depth of interest. The stress reduction factor $r_{d}$ is computed as, $r_{d}=1.0+1.6 * 10^{-6}\left(z^{4}-42 z^{4}+105 z^{2}-4200 z\right)$

Where, $\mathrm{z}$ is the depth below the ground surface in meters.

Moment magnitude is defined as a function of the seismic moment $\mathrm{M}_{0}$. This measures the extent of deformation at the earthquake source and can be evaluated as follows (Amr S. Elnashai and Luigi Di Sarno, 2008) [16, 18]:

$\mathrm{M}_{0}=\mathrm{G} A \Delta \mathrm{u}$

Where $G$ is the shear modulus of the material surrounding the fault, $\mathrm{A}$ is the fault rupture area and $\Delta$ $\mathrm{u}$ is the average slip between opposite sides of the fault. $\mathrm{M}_{\mathrm{w}}$ is computed by:

$\mathrm{M}_{\mathrm{w}}=0.67 \log \left(\mathrm{M}_{0}\right)-10.70$

Where, $\mathrm{M}_{0}$ is expressed in ergs.
Cornell, et al. (1979) proposed the mean of log peak ground acceleration (in units of $\mathrm{g}$ ) and peak ground acceleration is calculated with the source distance.

$\operatorname{Ln}(\mathrm{PGA})=-0.152+0.859 \mathrm{M}_{\mathrm{w}}-1.803 \ln (\mathrm{R}+25)$

Where, $\mathrm{PGA}=$ Peak ground acceleration

$\mathrm{M}_{\mathrm{w}}=$ Moment magnitude

$\mathrm{R}=$ Source Distance

If the computed cyclic resistance ratio (CRR) of the soil is less than or equal to cyclic stress ratio (CSR) generated due to the earthquake, the soil is suffered the liquefaction problem at that locations. The factor of safety against liquefaction (FS) is defined with (Ishihara, 1993) [17];

$$
\mathrm{FS}=\frac{\mathrm{CRR}}{\mathrm{CSR}}
$$

The soil with the depth of SPT profiles is predicted to liquefy if $\mathrm{FS} \leq 1.0$, while $\mathrm{FS}>1.0$ indicates no liquefaction.

To Liquefaction Potential Index (LPI) is a singlevalued parameter to evaluated regional liquefaction potential. LPI at a site is computed by integrating the factor of safety (FS) along the soil column. A weighting function is added to give more weight to the layers closer to the ground surface.

For the soil profiles, the Liquefaction Potential Index (LPI) proposed by Luna and Frost 1998 can be expressed as follows:

$\mathrm{LPI}=\sum_{\mathrm{i}=1}^{\mathrm{n}} \mathrm{F}_{\mathrm{i}}(\mathrm{z}) \mathrm{W}_{\mathrm{i}} \mathrm{H}_{\mathrm{i}}$

With

$\mathrm{F}_{\mathrm{i}}=1-\mathrm{FS}_{\mathrm{i}}$ for $\mathrm{FS}<1.0_{\mathrm{i}}$

$\mathrm{F}_{\mathrm{i}}=0$ for $\mathrm{FS} \geq 1.0_{\mathrm{i}}$

$\mathrm{W}_{\mathrm{i}}=10-0.5 \mathrm{Z}$ for $\mathrm{z} \leq 20 \mathrm{~m}$

$\mathrm{W}_{\mathrm{i}}=0$ for $\mathrm{z}>20 \mathrm{~m}$

Where $\mathrm{n}$ denotes the number of discretized layers, $\mathrm{H}_{\mathrm{i}}$ is the thickness of the discretized layer, and $\mathrm{F}_{\mathrm{i}}$ denotes the liquefaction severity for layer which is a function 
of the FS defined in Equation. Finally, $\mathrm{W}_{\mathrm{i}}$ is the the category adopted in this study is proposed, as weighting function as defined in Equation.

discussed below [1].

The categories of liquefaction severity were modified by Luna and Frost (1998) as shown in Table 1. Also,

Table 1. Historic liquefaction severity assessed from the liquefaction potential index (LPI)

\begin{tabular}{|c|c|c|}
\hline LPI & Iwasaki et al. (1982) & Luna and Frost (1998) \\
\hline $\mathbf{0}$ & Not likely & Little to none \\
\hline $\mathbf{0}<\mathbf{L P I} \leq \mathbf{5}$ & Minor & Minor \\
\hline $\mathbf{5}<$ LPI $\leq \mathbf{1 5}$ & - & Moderate \\
\hline $\mathbf{1 5}<$ LPI $\leq \mathbf{1 0 0}$ & Severe & Major \\
\hline
\end{tabular}

The evaluation of the liquefaction potential index (LPI) predicts surface detection of liquefaction, liquefaction damage or failure potential of a liquefaction-prone area. The LPI is computed by integrating the FS values over the depth of soil columns limited to the depths ranging from 0 to $20 \mathrm{~m}$ below the natural ground surface, providing an assessment of liquefaction-related surface damage.

The factor safety of soil during strong earthquakes with different magnitudes is calculated by using equation. 9. Factor of safety (FS) against liquefaction is evaluated corresponding to different earthquakes $7.26,7.5,7.66,7.93$ and $8.13 \mathrm{M}_{\mathrm{w}}$ with peak ground acceleration $0.21 \mathrm{~g}, 0.25 \mathrm{~g}, 0.29 \mathrm{~g}, 0.36 \mathrm{~g}$ and $0.43 \mathrm{~g}$.

\section{SOIL INVESTIGATION AND SOIL DISTRIBUTION MAP}

Soil investigation, called geotechnical investigation, is the important thing to design about the structure construction. It is to test the physical properties on site to understand the ground conditions for geotechnical design (foundations, retaining walls \& soil improvement). There are three basic types of soil condition: sand, silt and clay. Soil distribution map is a map to show the soil types and is very useful tool for geotechnical engineering.

The twenty nine townships in this city are selected as the study area for the research. Data collection is the hardest parts of the research work which consumed time and 530 bore $\operatorname{logs}$ are collected for the liquefaction analysis. The borehole records contained the geotechnical information such as grain size distribution, Atterberg limits, N-values, moisture content, density and unit weight. The location map of boreholes is presented in Fig 2.
Soil distribution maps at different depth are analyzed by using Unified Soil Classification System. There are seven soil types such as SM (Silty Sand), CL (Clay with Low Plasticity), $\mathrm{CH}$ (Clay with High Plasticity), MH (Silt with High Plasticity), ML (Silt with Low Plasticity), and SC (Clayey Sand) in these maps. In this research, soil distribution maps are developed by using ArcGIS software at Yangon area.

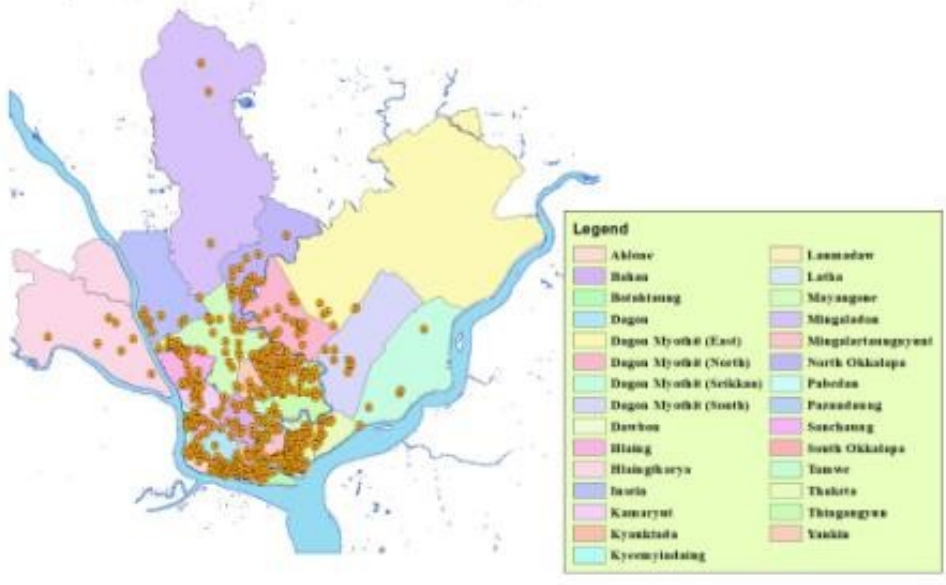

Figure 2. Location Map of Boreholes

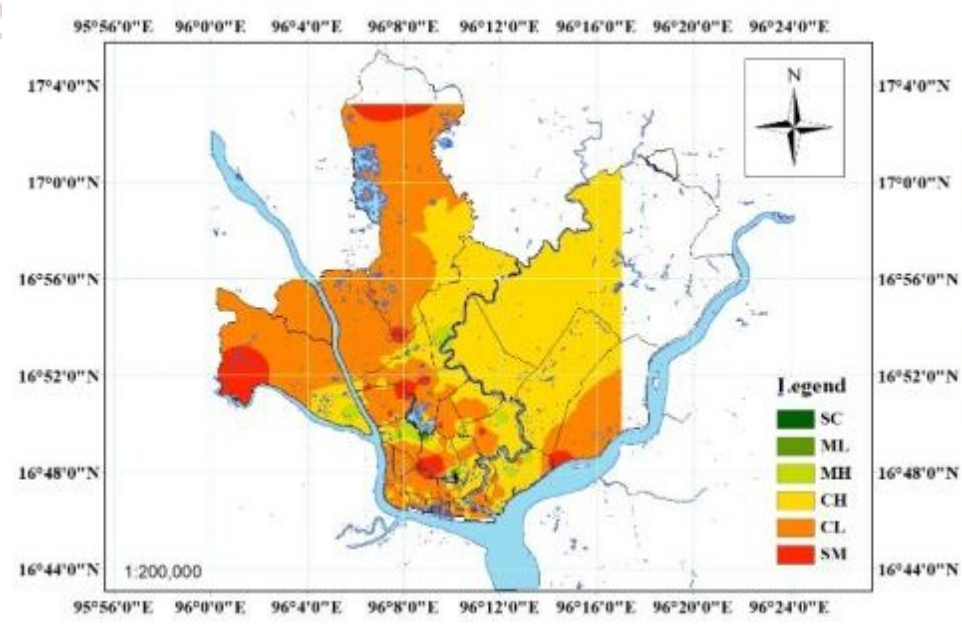

Figure 3. Soil Distribution Map at $5 \mathrm{~m}$ Depth 


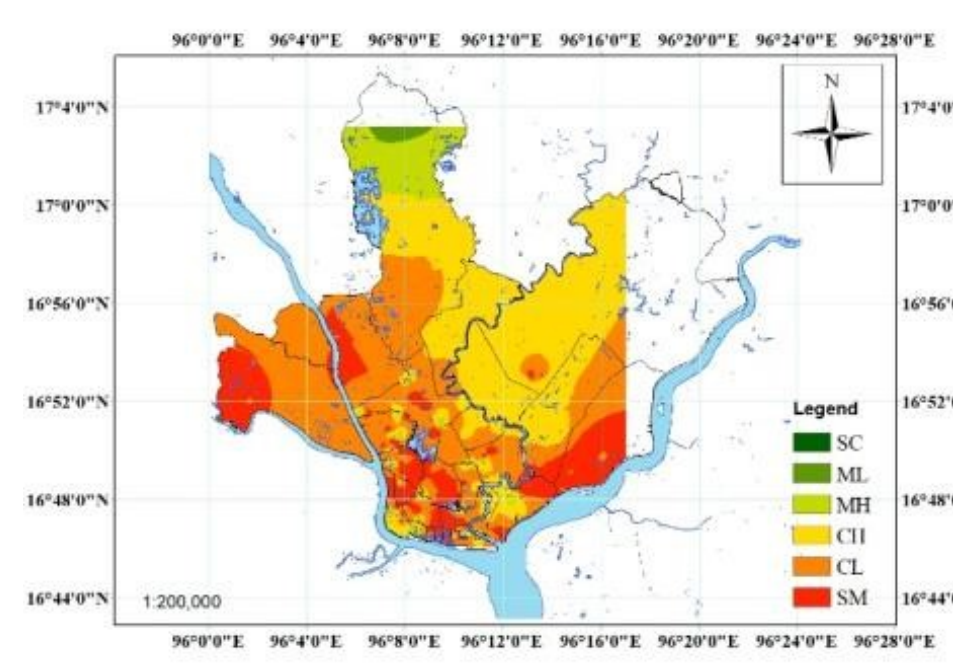

Figure 4. Soil Distribution Map at 10 m Depth

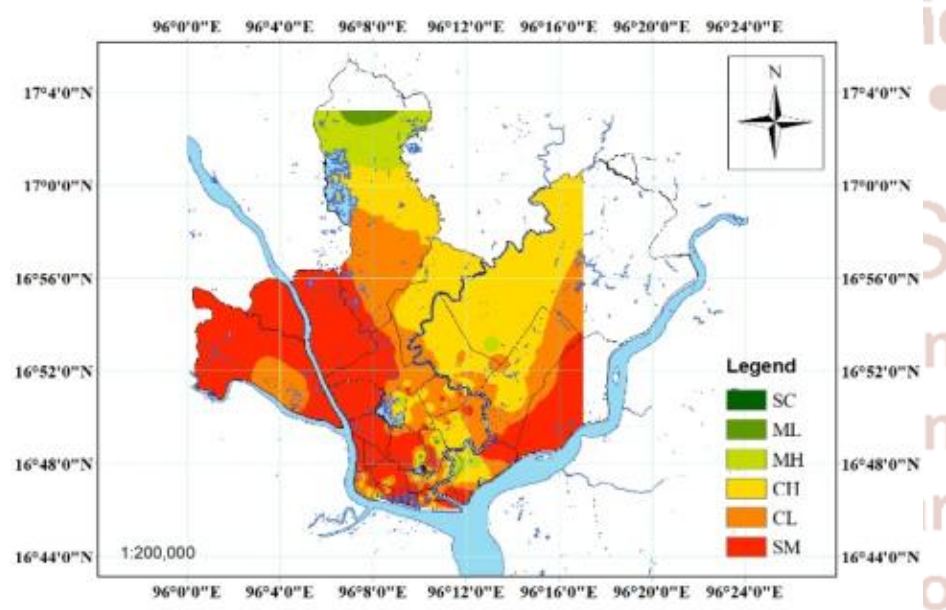

Figure 5. Soil Distribution Map at 15 m Depth

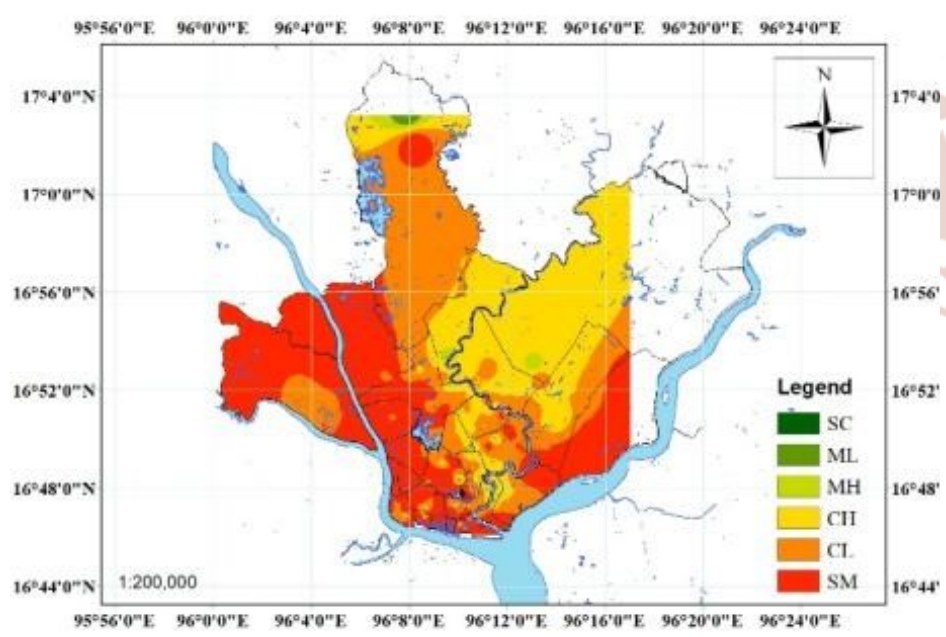

Figure 6. Soil Distribution Map at 20 m Depth

The most area of Yangon City, namely Hlaing, Mayangone, Insein, Mingalartaungnyut, South Okkalarpa, Thingangyun, Thekata and Ahlone
Townships are covered by the $\mathrm{CH}$ soil type up to $5 \mathrm{~m}$ depth in Fig 3. Some area such as Hlaing, Hlaingtharyar, Mayangone, South Okkalarpa, Mingalartaungnyut, Ahlone and Tarmwe Townships are covered by $\mathrm{CH}$ soil type between $5 \mathrm{~m}$ and $10 \mathrm{~m}$ shown in Fig 4. In Hlaing, Mayangone, Insein, Yankin, Mingalartaungnyut and Ahlone Townships, it is found that CL soil type mostly covered between 10 $\mathrm{m}$ and $15 \mathrm{~m}$ depth in Fig 5. The SM and $\mathrm{CH}$ soil type is covered in Yangon area at $20 \mathrm{~m}$ depth. The soil liquefaction has been occurred in silty sand during earthquakes shown in Fig 6. Therefore, the development of liquefaction potential map is needed for these study area.

\section{Liquefaction Potential Mapping}

In this research, the safety factor (FS) against liquefaction of five hundred and thirty (530) borehole locations is evaluated by NCEER Method. The FS at different soil profiles is calculated by using different earthquake magnitudes such as 7.26, 7.5, 7.66, 7.93 and $8.13 \mathrm{M}_{\mathrm{w}}$ with peak ground acceleration $0.21 \mathrm{~g}$, $0.25 \mathrm{~g}, 0.29 \mathrm{~g}, 0.36 \mathrm{~g}$ and $0.43 \mathrm{~g}$. Liquefaction potential index (LPI) values for different site locations are computed by using Luna and Frost Method. Liquefaction assessments are categorized based on LPI values. i.e. none to little for $\mathrm{LPI}=0$, minor for 0 $<\mathrm{LPI} \leq 5$, moderate for $5<\mathrm{LPI} \leq 15$ and major for LPI $>15$. Liquefaction potential map plays an important role to know liquefaction susceptibility at specific locations. Liquefaction Potential Maps are developed by ArcGIS software shown in Fig: 7, 8 9, 10 and 11. It was shown that the liquefaction potential map was developed for $1 \%$ probability of exceedancce in 50 years with moment magnitude $\mathrm{M}_{\mathrm{w}}$ $=8.13$ and $\mathrm{a}_{\max }=0.43 \mathrm{~g}$ in Fig 7 . The liquefaction potential map for $2 \%$ probability of exceedance in 50 years with $\mathrm{M}_{\mathrm{w}}=7.93$ and $\mathrm{a}_{\max }=0.36 \mathrm{~g}$ was prepared in Fig. 8. The liquefaction potential map was developed with $5 \%$ probability of exceedance in 50 years $\left(\mathrm{M}_{\mathrm{w}}=7.66\right.$ and $\left.\mathrm{a}_{\max }=0.29\right)$ shown in Fig 9. In Fig. 10, the liquefaction map for $10 \%$ probability of exceedance in 50 years with moment magnitude $\mathrm{Mw}$ $=7.5$ and $\mathrm{a}_{\max }=0.25 \mathrm{~g}$ was prepared. The development of liquefaction potential map for $20 \%$ probability of exceedance in 50 years with $\mathrm{Mw}=7.26$ and $\mathrm{a}_{\max }=0.21 \mathrm{~g}$ was shown in Fig 11. The LPI values of the area around the river are higher than other area in this city. 


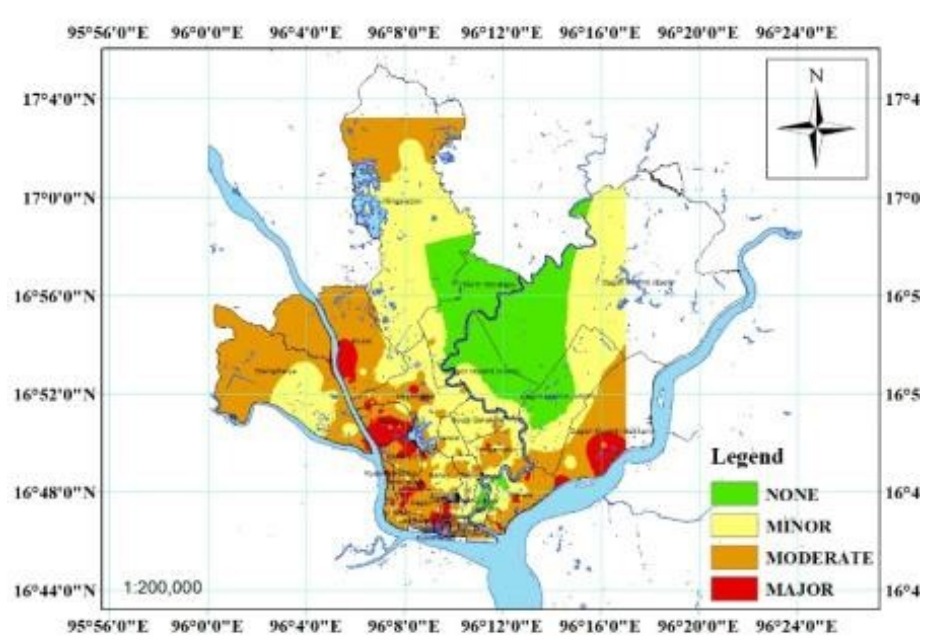

Figure 7. Liquefaction potential map for $1 \%$ probability of exceedance in 50 years

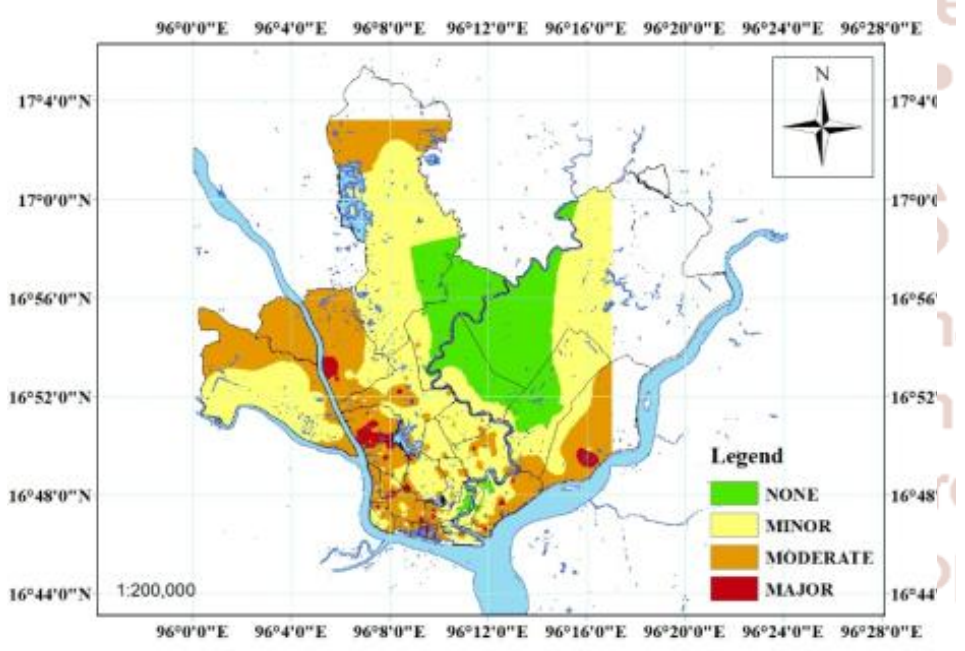

Figure 8. Liquefaction potential map for $2 \%$ probability of exceedance in 50 years

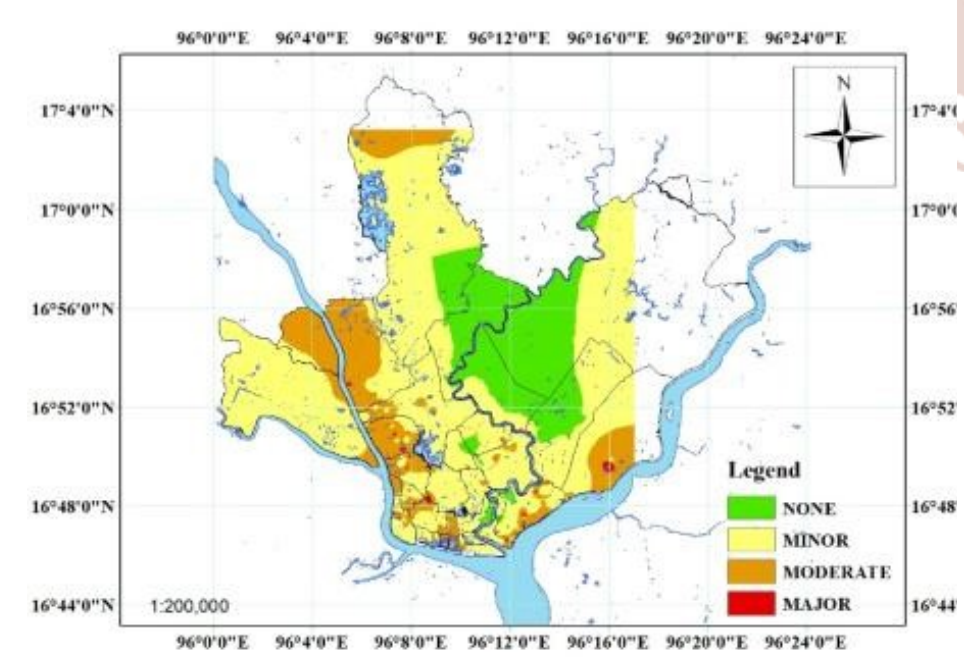

Figure 9. Liquefaction potential map for 5\% probability of exceedance in 50 years

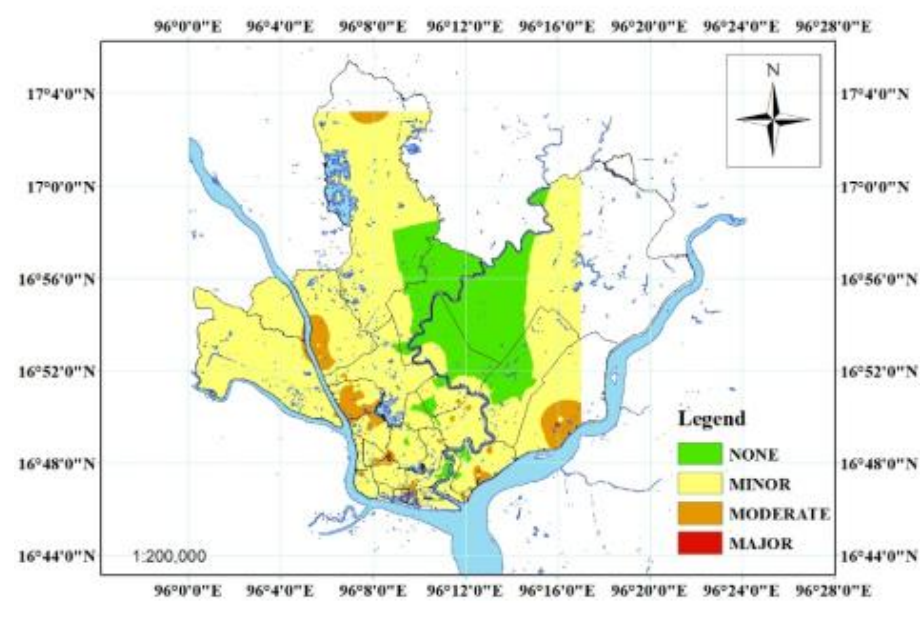

Figure 10. Liquefaction potential map for $10 \%$ probability of exceedance in 50 years

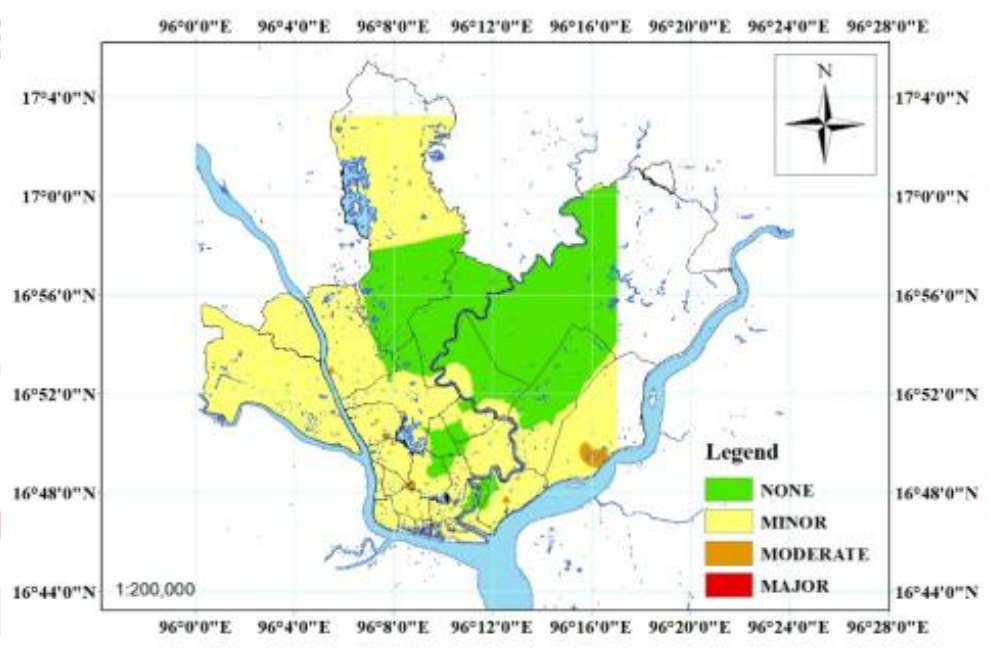

Figure 11. Liquefaction potential map for $20 \%$ probability of exceedance in 50 years

\section{RESULTS AND DISCUSSIONS}

The liquefaction potential map of Yangon City offers a quantitative approach for mapping liquefaction susceptibility. The Yangon City area are taken as the study area for evaluation of liquefaction potential of soil. A total of 530 numbers of borehole data in Yangon City, both undisturbed and disturbed soil test reports were supported by Yangon City Development Committee and professionals working in geotechnical engineering field. In this research, factor safety against liquefaction (FS) and corresponding liquefaction potential indices (LPI) for the seismic scenario were evaluated using SPT based semiempirical producers.

The liquefaction susceptibility at different sites in Yangon City is shown in LPI maps. Liquefaction potential maps for earthquakes such as $1 \%, 2 \%, 5 \%$, 
$10 \%$ and $20 \%$ probability of exceedance in 50 years are analyzed by using LPI values. The maps of LPI are developed for the city to predict the occurrence of liquefaction damages for the earthquake magnitudes such as $\mathrm{M}_{\mathrm{w}}=7.26, \mathrm{M}_{\mathrm{w}}=7.5, \mathrm{M}_{\mathrm{w}}=7.66, \mathrm{M}_{\mathrm{w}}=7.93$ and $\mathrm{M}_{\mathrm{w}}=8.13$ of $\mathrm{a}_{\max }$ level $0.21 \mathrm{~g}, 0.25 \mathrm{~g}, 0.29 \mathrm{~g}, 0.36$ $\mathrm{g}$ and $0.43 \mathrm{~g}$ shown in Fig 7, 8, 9, 10 and 11 of the previous section. The liquefaction potential maps showed the liquefaction vulnerability at different sites of the city. The liquefaction susceptibility for sites with LPI $>15$ is very high and the liquefaction is very unlikely at sites with LPI $<5$.

Most of the area is minor and moderate of liquefaction with $1 \%$ probability of exceedance in 50 years as shown Fig: 7. Some area is suffered the major liquefaction problem. The LPI values of the area are varied from 16.75 to 52.09 in the figure. As can be seen in Fig: 8, Hlaing, Insein and Kamaryut Twonships are moderate and major of liquefaction susceptibility and most of the townships was lower than 5 for $2 \%$ probability of exceedance in 50 years. LPI values arranged from 13.69 to 48.51 shown in figure. Insein, Hlaing and Kamaryut Twonships are moderate of liquefaction susceptibility and most of the townships are minor of liquefaction susceptibiliy for $5 \%$ probability of exceedance in 50 years shown in Fig 9. The LPI values varied from 15 to 42.73 . Some of the area of city; namely Inseing Hlaing and Dagon Myothit Seikkan Townships are moderate of liquefaction susceptibility and the other townships are minor of liquefaction susceptibility for $10 \%$ probability of exceedance in 50 years as shown in Fig: 10. There is no major to liquefaction susceptibility in the map. In Fig 11, most of the areas are minor of liquefaction susceptibility for $20 \%$ probability of exceedance in 50 years. Other townships are minor state of liquefaction problem.

The liquefaction potential maps are proposed by five earthquake levels with $20 \mathrm{~m}$ depth of soil profiles. The results showed that the thickness of discrete soil layer and blow accounts are very important parameters in soil liquefaction. The liquefaction potential maps shown in figures serves as useful tools for geotechnical engineering to mitigate liquefaction hazards in future earthquakes. In this research, these maps are suitable for deep foundation in Yangon City.

\section{CONCLUSION}

The liquefaction potential maps for this study revealed that the selected areas are higher for liquefaction susceptibility during $1 \%$ probability of exceedance in 50 years. The seismological aspects such as ground motion levels and earthquake magnitudes are the most important factors of liquefaction potential. The appropriate peak horizontal ground acceleration for the scenario earthquake can be chosen one of the uncertain factors for future study. The liquefaction potential of the Yangon city varied from none to major liquefaction susceptibility. LPI value of each SPT profile is evaluated from the safety factor that is estimated using the NCEER method. The liquefaction potential maps were generated for Yangon city to predict the occurrence of damaging liquefaction for different moment magnitudes. In this research, the liquefaction potential maps were developed for Yangon city to predict the occurring liquefaction damages for $1 \%, 2 \%, 5 \%, 10 \%$ and $20 \%$ probabilities of exceedance in 50 years. These maps will benefit for the designers and practicing engineers to identify liquefaction vulnerability of the proposed work at particular area in Yangon City.

\section{Acknowledgments}

The authors are grateful for the Yangon City Development Committee, Committee for Quality Control of High-Rise Building Construction Projects in Myanmar and professional working in geotechnical engineering field for providing the borehole data at different sites in the study area.

\section{References}

1) T.I. Mote J.N. Dismuke. "Liquefaction hazard maps for Australia." Proceedings of the 15th WCEE World Conferences on Earthquake Engineering, 2012.

2) T. L. Youd, Member, ASCE, and I. M. Idriss, Fellow. "Liquefaction Resistance of the Soils: Summary Report from the 1996 NCEER and 1998 NCEER/NSF Workshops on Evaluation of Liquefaction Resistance of Soils." Journal of Geotechnical and Geoenvironmental Engineering 127, April 2001, 297-311.

3) J. Dixit, D. M. Dewaikar, and R. S. Jangid. "Assessment of Liquefaction Potential Index for Mumbai City." Journal of Natural Hazards and Earth System Sciences. 
4) Md. Zilllur Rahman, Sumi Siddiqua and A.S.M. Maksud Kamal. "Liquefaction Hazard Mapping by Liquefaction Potential Index for Dhaka City, Bangladesh.” Enigneering Geology 188, April 2015, 137-147.

5) Alan F. Rauch "Empirical Method for Predicting Surface Displacements due to LiquefactionInduced Lateral Spreading in Earthquake”, May 1997.

6) David Kun Li , C. Hsein Juang and Ronald D. Andrus. "Liquefaction Potential Index: a Critical Assessment using Probability Concept." Journal of GeoEngineering 1, August.

7) Rama Mohan Pokhrel, Jiro Kuwana, Shinya Tachiban. "A Kriging Method of Interpolation Used to Map Liquefaction Potential over Alluvial Ground." Journal of Engineering Geology 152, January 2013, 26-37.

8) Sumedh Yamaji Mhaske and Deepankar Choudhury. "GIS-based Soil Liquefaction Susceptibility Map of Mumbai City for Earthquake Events." Journal of Applied Geophysics 70, March 2010, 216-225.

9) Myo Thant. "Probabilistic Seismic "Hazard Assessment for Yangon Region, Myanmar." Journal of ASEAN Engineering Part C , December 2012, 117-132.

10) Griffen L. Erickson, Steven F. Bartlett, Barry J. Solomon, Loren R. Anderson and Michael J. Olsen. "Probabilistic Liquefaction Potential Mapping of Salt Lake Valley, Utah".

11) Jennifer A. Lenz, Laurie G. Baise. "Spatial Variability of Liquefaction Potential in Regional Mapping using CPT and SPT Data." Soil
Dynamics and Earthquake Engineering 27, July 2007, 690-702.

12) Ross W. Boulanger and I. M. Idriss. "Probabilistic Standard Penetration Test-Based LiquefactionTriggering Procedure." Journal of Geotechnical and Geoenvironmental Engineering 138, October 2012.

13)C. Hsein Juang and Tao Jiang. "Assessing Probability-Based Methods for Liquefaction Potential Evaluation." Journal of Geotechnical and Geoenvironmental Engineering 128, (July 2002, 580-589.

14) Debojit Sarker and Mehedi Ahmed Ansary. "Assessment of Liquefaction Potential Index for Approach Road of Padma Multipurpose Bridge." Journal of Mechanical and Civil Engineering 12, April 2015.

15) Shpresa Gashi and Neritan Shkodrani. "Seismic Soil Liquefaction for Deterministic and Probabilistic Approach Based on in Situ Test (CPTU) Data." World Journal of Engineering and Technology 3, May 2015, 41-49.

16) Ronaldo Luna and J.David Frose. "Spatial Liquefaction Analysis System." Journal of Computing in Civil Engineering 12, January 1998, 48-56.

17) I. M. Idriss and Ross W. Boulanger, "SPT-Based Liquefaction Triggering Procedures”, 2010.

18) Zar Lee Tint, Nyan Myint Kyaw and Kyaw Kyaw, "Development of Soil Distribution and Liquefaction Potential Maps for Downtown Area in Yangon, Myanmar." Civil Engineering Journal, April 2018, 689-701. 